\title{
Envisioning alternative futures of cultural ecosystem services supply in the coastal landscapes of Southwestern Ghana, West Africa
}

\author{
Stephen Kankam ${ }^{1,2}\left[\right.$ ] Justice Nana Inkoom ${ }^{1,2} \cdot$ Hongmi Koo $^{1} \cdot$ Christine Fürst $^{1}$
}

Received: 3 June 2021 / Accepted: 9 August 2021 / Published online: 8 September 2021

(c) The Author(s) 2021

\begin{abstract}
Cultural ecosystem services (CES) in Southwestern Ghana evoke a strong sense of attachment of local land users to the landscape. Hence, their supply is necessary for a balanced socio-ecological system. This study explored the potential supply of cultural ecosystem services (science/education, spiritual, tourism, health and recreation benefits) under different land use planning (LUP) scenarios in Southwestern Ghana. Future LUP scenarios were developed and articulated with a diverse group of land-use planning actors (LUPAs) such as regional land use planners, environmental experts, researchers, farmers and landowners. The scenarios covered business-as-usual, mangrove ecosystem restoration, market-driven growth, and the establishment of an "eco-corridor" as green network. A spatially explicit modeling platform, GISCAME, which combines Geographic Information System and Cellular Automaton modules and multicriteria evaluation was used to evaluate the developed scenarios. Outcomes of the study revealed that in the coastal landscape of Southwestern Ghana, values, perceptions and preferences of LUPAs underpin socio-ecological interactions aimed at maintaining and enhancing CES supply. In addition, it indicated that future supply of CES is characterized by an interplay between multiple and diverse perspectives about plausible land-use futures. Perceptions of, and preferences for, CES align with land-use visions related to afforestation, infrastructure development, agriculture expansion and tourism. In the study area and similar contexts where an array and diversity of individual and societal values exist, effective negotiation and facilitation are essential for harnessing and optimizing land-use planning for CES supply.
\end{abstract}

Keywords Cultural ecosystem services $\cdot$ GISCAME $\cdot$ Land-use planning actors $\cdot$ Land-use scenarios $\cdot$ Socio-ecological system

\section{Cultural ecosystem services valuation for landscape planning}

Cultural ecosystem services (CES) are inexorably linked to human well-being (de Groot et al. 2010, p 264; MEA 2005, pp 71-83). They are variously defined as the "nonmaterial outputs of ecosystems that affect the physical and mental states of people" (Haines-Young and Potschin 2013, p ii); and the "non-material benefits people derive from ecosystems" (MEA 2005, p 57). Consequently, CES integration

Stephen Kankam

skankam@henmpoano.org

1 Martin Luther University Halle-Wittenberg, Institute for Geosciences and Geography, Department of Sustainable Landscape Development, Von-Seckenorff-platz 4, 06120 Halle (Saale), Germany

2 Hen Mpoano (Our Coast), Sekondi-Takoradi, Ghana into landscape planning and conservation decisions motivates public protection of ecosystems (Daniel et al. 2012, p. 8813; Plieninger et al. 2015, pp 29-30). However, challenges remain in translating CES into mainstream land use policy and for applications in landscape planning and management. This peculiar barrier relates to difficulties with the definition and quantification of CES (Dickinson and Hobbs 2017, p 182; Blicharska et al. 2017, p 56). A common feature of most CES is their incommensurability and intangibility, which renders, them almost impossible to measure or subjected to comparison, unless experienced (Dickinson and Hobbs 2017, p 183). Hence, utilization of market-based metrics for CES valuation risks exclusion of a wide array of CES in land use decision making (Chan et al. 2012a, b, pp 744-745). This is because human agency required for co-production of CES is based on perceptions and mindset transformation rather than capital, labor or technological inputs (Dickinson and Hobbs 2017, p 184). Furthermore, landscape changes 
are largely driven by human values (García-Llorente et al. 2012, p 137).

Values in this context connote the importance individuals or groups of people attach to CES (Brown et al. 2016, p 2; Scholte et al. 2015, p 68; de Groot et al. 2010, p 262). Alternative approaches to CES identification and valuation for landscape planning and management have relied on characterizations based on broader socio-cultural values and perspectives (Chan et al. 2012a, b, pp 8-18; MartínLópez et al. 2012, pp 1-11) rather than restricting analysis to monetary factors. Utilization of participatory approaches has also enabled inclusion of a wide range of value domains to explore the roles of CES in landscape planning through solicitation of the diverse stakeholder perceptions and preferences within varied coastal landscapes and socio-cultural contexts (see Brown and Hausner 2017, pp 49-60). Furthermore, combination of participatory and spatially explicit valuation of CES allows identification and quantification of non-instrumental values as a means of bridging assigned values (physical features) and held values (object of importance) of CES users (Brown et al. 2016, p 2; Brown and Weber 2013, pp 192-208). Thus, participatory and spatially explicit mapping approaches are well suited for understanding the place-based and site-specific characteristics of CES (Jones et al. 2020; pp 124-137; Brown and Fagerholm 2015, p 120).

Incorporating the diverse stakeholder perceptions of CES in landscape planning has the potential of enhancing legitimacy of conservation land use plans and improving public support for their future implementation. Nonetheless, personal experiences introduce subjectivity in the appreciation of CES; hence, broad citizen participation is advocated in landscape planning and ecosystem management (Burkhard and Maes 2017, p 205). However, negotiating trade-offs among stakeholders and their diversity of values to produce sustainable outcomes in a socio-ecological system is a complex exercise in land management (Ellis et al. 2019, pp 86-87).

Recent advances in negotiating alternative land use visions have relied on participatory scenario planning. In the context of LUP, scenarios serve as decision support tools by incorporating multiple perspectives and sources of local knowledge through stakeholder-based visioning processes. The Intergovernmental Science-Policy Platform on Biodiversity and Ecosystem Services (IPBES) has utilized scenarios to define visions of alternative futures of ecosystem services (ES), including CES, in Africa (IPBES 2018, pp xli-xlii). Scenarios have also been simulated and visualized in spatially explicit assessments of ES and for illustrating alternative land-use pathways in Northern Ghana (Koo et al. 2018, pp 1-21). However, the usefulness of land-use scenarios lies in their unique opportunity to nurture the mind, challenge ideologies, share ideas, inspire creativity and reinforce ecological ethics in socio-ecological practice (Xiang and Clarke 2003, pp 889-890). In socio-ecological practice, actors in the social system pursue actions that strive to attain sustainable outcomes in human-environment interactions through planning, design, construction, restoration, conservation and management (Xiang 2019, p 7). Recently, scenario-based research in land use planning has witnessed a shift from normative scenarios to the use of exploratory scenarios to address uncertainty and identify plausible and sustainable future land use pathways (Avin and Goodspeed 2020, pp 403-404; Plieninger et al. 2013, pp 1-16). Typically, in a rapidly changing landscape, exploratory scenario planning serves as a tool for stakeholders to analyze future uncertainties and complexities characterizing ecosystembased management and related supply of ES (Plieninger et al. 2013, pp 1-16; Malinga et al. 2013, pp 1-22).

In the coastal landscapes of Southwestern Ghana, sustainable supply of ES faces an uncertain future due to multiple pressures driving rapid land use changes in this region (CEPF 2000, p 80; Daniels et al. 2021, p 11; Kankam et al. in preparation). Confronted with such coastal zone pressures, spatially explicit and empirical CES assessments are urgently required to facilitate integrated coastal landscape planning to ensure that people and nature benefit simultaneously from conservation and the development of coastal areas (Brown and Hausner 2017, p 50). Unfortunately, CES are not well understood and explored in Southwestern Ghana, thereby rendering their omission in regional and municipal spatial planning and landscape management (see MEST 2012, pp 1-195).

The present study aims to explore potential supply of CES under a business-as-usual (BAU) and alternative LUP scenarios using participatory and spatially explicit valuation approaches. We anticipate that land-use planning actors (LUPAs) have divergent perceptions of, and preferences for, land-use systems (Kleemann et al. 2017, pp 284-286) and the differences influence the regional potential to supply CES. Specifically, the study explores how LUP alternatives influence CES supply in the study location. It further characterizes the influence of different perceptions and preferences of LUPAs on scenario outcomes for CES supply. Finally, the study examines trade-offs and synergies between different CES to inform future land use decision-making and enhance the sustainability of CES supply.

\section{Description of study area}

The study area is situated within the Upper Guinean Forests eco-region which is defined as a biodiversity hotspot (CEPF 2000, pp 1-2). In Ghana, the study area lies in the Wet Evergreen Forest zone, and forms a part of the Greater Amanzule Wetlands (GAW) of Southwestern Ghana. Covering 


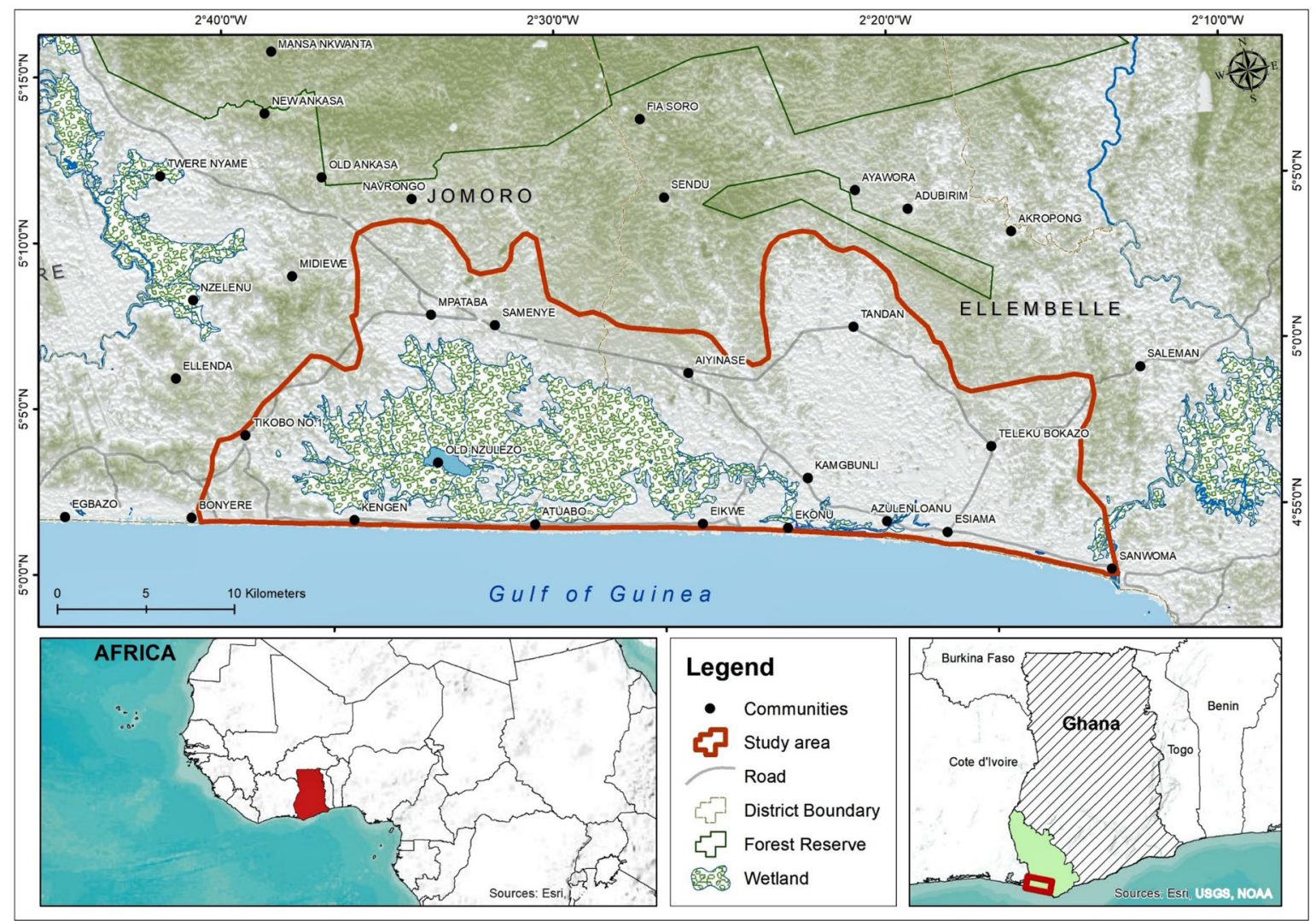

Fig. 1 Map of Southwestern Ghana showing study area

approximately, $362 \mathrm{~km}^{2}$, the study area extends from the Ankobra river estuary and stretches towards the Tano basin on Ghana's southwestern boundary with Cote d'Ivoire (see Fig. 1). The area is characterized by a bi-modal rainfall regime, with peak rainfall in May to June and October to November each year. Mean annual rainfall is $1600 \mathrm{~mm}$ with a relative humidity of $87.5 \%$ (Ajonina 2011, p 7). It encompasses a relatively pristine and vast expanse of coastal ecosystems comprising swamp forests, freshwater lagoons, rivers, mangrove forests, terrestrial forests, agricultural lands and grasslands. Thus, this region is characterized by a relatively high diversity of flora and fauna (237 species of plants; 27 species of mammals and 26 species of demersal fish), including forest primate species (Osei et al. 2015, pp 25-40). The study area traverses three administrative boundaries in Southwestern Ghana, namely Nzema East Municipal Area, Ellembelle Municipal Area and Jomoro District. Characterized as a regional peatland ecosystem, this area is key to maintenance of regional water balance, conservation of wildlife habitats and mitigating climate change (Amoakoh et al. 2021, pp 3-4). The landscape supports fisheries and agriculture-based livelihoods of an estimated 100,000 local inhabitants. Majority of the local residents are farmers and fishers. Development of off-shore oil and gas resources off the coast of southwestern Ghana has subjected the coastal area to different land use intensities and to growing land use competition (Coastal Resources Center 2010, pp 11-23). There is over-dependence on mangrove forests by coastal dwellers for fish smoking while adjacent terrestrial forests are threatened by deforestation resulting from mining activities. These land use pressures are changing the governance dynamics of a predominantly community-managed coastal landscape.

Recognizing these pressures on a coastal landscape of regional and national importance, state and non-state actors have initiated policies, plans and programs to address challenges confronting the coastal socio-ecological system. Hence, the coastal landscape has been the focus of spatial planning and ecosystem based-management initiatives spearheaded by environmental non-governmental organizations (NGOs), researchers, public agencies, local citizens and private sector entities.

\subsection{Methodological framework}

In this study, we utilized mixed methods which combined participatory approaches and a spatially explicit assessment method for identifying the impacts of alternative LUP 


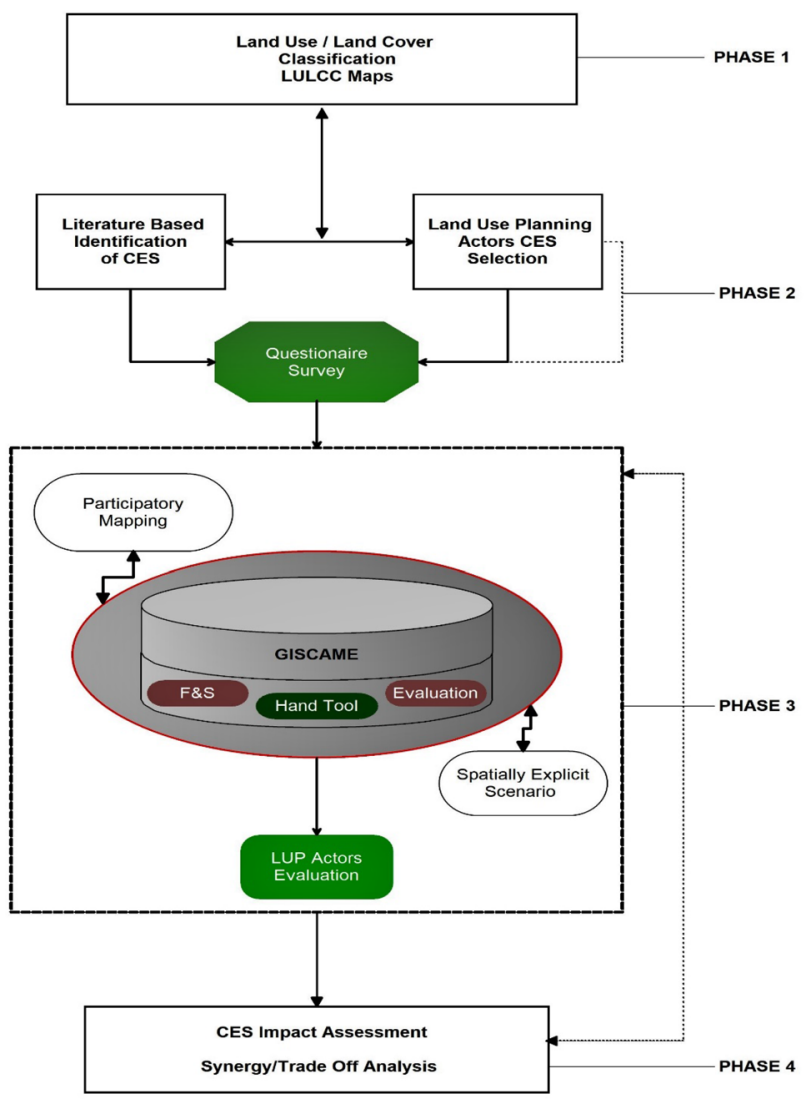

Fig. 2 Methodological framework for assessing land use scenario impacts on future supply of cultural ecosystem services

(land-use planning) scenarios on the potential of CES supply in the region of southwestern Ghana. The assessment process consisted of four phases (Fig. 2). In the first phase, we classified the land-use/land-cover (LULC) and generated related LULC maps to characterize the existing biophysical situation in the study region (see sub-Sect. 2.2). The second and third phases enabled the collection and integration of LUPAs knowledge into scenario composition (see sub-Sect. 2.4). These phases comprised organizing workshops that allowed LUPAs to select and rank relevant CES and also adapt their definitions to reflect the regional context (see sub-Sect. 2.4.1). In the context of this study, LUPAs are considered to be the individuals, organizations or interest groups with a common interest to participate in a LUP process (Ligtenberg et al. 2001, p 44). Additionally, we utilized a spatially explicit modeling platform, GIS$\mathrm{CAME},{ }^{1}$ to generate spatially explicit land-use scenarios based on participatory mapping exercises with the LUPAs

\footnotetext{
${ }^{1}$ Geographic Information System Cellular Automaton Multi-criteria Evaluation (GISCAME) formerly known as "Pimp Your Landscape" (Source: http://www.giscame.com/giscame/english.html).
}

(see sub-Sect. 2.4.2). As illustrated in Fig. 2, GISCAME provides tools for participatory mapping and visualization of land-use scenario impacts under specified environmental conditions. This modelling platform also combines a cellular automaton with GIS features and a multi-criteria assessment approach (Fürst et al. 2010, pp 1-25; Koschke et al. 2012, p 59). Questionnaires were administered to elicit the perception of LUPAs on the potential supply of selected CES according to the LULC types (see sub-Sect. 2.4.3). In the fourth phase of the assessment, an evaluation was performed using GISCAME, to determine the regional potential to supply CES under different LUP scenarios. This revealed potential trade-offs and synergies between perceptions and preferences of LUPAs and the sustainability of CES supply (see sub-Sect. 2.5).

\subsection{Land-use/land-cover classification}

To generate LULC maps, Landsat 5 TM (Thematic Mapper) data of 2000/2002 and Landsat 8 OLI (Operational Land Imager) data of 2016/2018 provided by the USGS (United States Geological Survey) Earth Explorer database system were utilized. The raw images were taken during the same season and free of cloud cover. Dataset obtained from February 02,2000 , and January 26,2018 , comprised the two time periods selected for further processing. Subsequently, processing and post-classification steps were completed using the software packages Erdas Imagine 2015 and ArcGIS v17.1. Prior to interpretation, image pre-processing, including geometric and radiometric corrections, was performed for each of the images. Data were geometrically corrected and projected to the Universal Transverse Mercator (UTM) zone $30 \mathrm{~N}$. After image pre-processing, supervised classification methods and maximum likelihood algorithms were used for preparing LULC maps and the derived LULC categories were assigned according to the descriptions of the Land Cover Classification System (LCCS). The LCCS is a hierarchical a priori classification scheme which provides a flexible framework for identifying land use classes in highly heterogeneous landscapes such as those found in the study area (Di Gregorio and Jansen 2000, pp 12-36). Eight landcover classes were derived and change analysis conducted using the Land Change Modeler embedded in the Idrissi TerrSet software (see Table 1, and Fig. 3).

\subsection{Identification of land-use planning actors}

We utilized the criteria indicated in Table 2 to select representatives of researchers, land use planners, land owners, farmers and NGO professionals for the workshop on identification of relevant CES. Selection and inclusion of these LUPAs in the workshop were based on their individual and collective influences on LUP and land management 
Table 1 Description of LULC types and their changes in the study area in 2000 and 2018

\begin{tabular}{lrrl}
\hline LULC types & \multicolumn{2}{c}{ Extent $(\%)$} & Description \\
\cline { 2 - 3 } & 2000 & 2018 & \\
\hline Mangroves & 1.18 & 1.07 & $\begin{array}{c}\text { Coastal forests of stilted shrubs or trees bordering the ocean or coastal estuaries, composed of one } \\
\text { or several mangrove species }\end{array}$ \\
Wetlands & 34.93 & 34.15 & Herbaceous or aquatic vegetation in permanent or semi-permanent swamps \\
Rubber plantation & 1.49 & 5.38 & Regular stands of trees planted for the purpose of producing materials for industry \\
Artificial areas/bare areas & 7.02 & 11.74 & Defined as cover resulting from human activities such as urban development, extraction or deposi- \\
& & & tion of materials. It comprises areas which are not covered by vegetation such as rocky or sandy \\
& 23.89 & 35.30 & Mix crops and non-forest vegetation with croplands representing more than 50\% of the cover \\
Rainfed cropland & 10.71 & 3.55 & Mixed mapping unit which consists of 50-70\% grassland \\
Grassland & 19.39 & 8.34 & A class representing a mapping unit which contains 20-10\% to 1\% vegetative cover \\
Shrubland/sparse vegetation & 1.39 & 0.47 & Areas covered by natural water bodies such as ocean, lakes, ponds, rivers or streams \\
Water bodies & & &
\end{tabular}

Source: Adapted from Di Gregorio A, and Jansen LJM (2000) pp 12-36

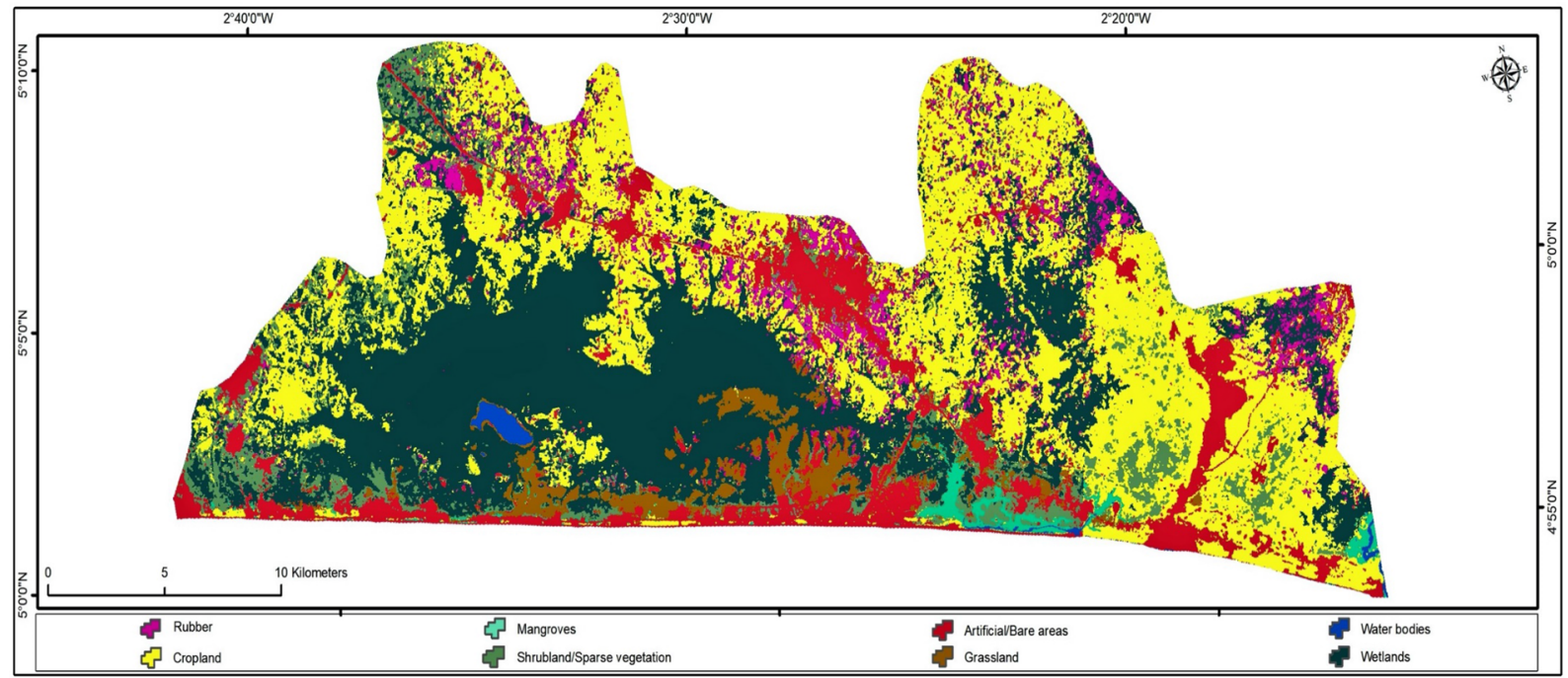

Fig. 3 Major land-use/land-cover types in the study area

decision-making processes in the study region (Acheampong 2019, p 162; Kleemann et al. 2017, pp 284-286). Regarding Ghanaian spatial governance context, farmers/ landowners are key decision-makers and implementers of land-use plans at the parcel level. Researchers and environmental NGO professionals are boundary actors. Their key functions in the planning process involve bridging knowledge and enhancing communication between diverse stakeholders (Mwangi and Wardell 2013, p 90). Regional and municipal LUP officials provide the requisite technical inputs for land-use plans preparation and final approval of plans. It is important to note that the participation of these actors in LUP is sanctioned by Ghana's tiered system of decentralized spatial governance (Agyemang et al. 2017, pp 72-73; MEST 2011, p 37).

\subsection{Collection and integration of land-use planning actors' knowledge}

\subsubsection{Identification of relevant cultural ecosystem services}

A list of CES was compiled from literature on the basis of ES classification and typology of Burkhard et al. (2009, p 18), MEA (2005, pp 58-59) and Peh et al. (2017, pp 220-221) and provided to LUPAs as input during a workshop organized for their identification of CES which are relevant to the regional context. The LUPAs were asked to 
Table 2 Profile of selected land-use planning actors, selection criteria and motivation for grouping in workshop sessions

\begin{tabular}{|c|c|c|c|c|c|}
\hline Grouping & $\begin{array}{l}\text { No. of } \\
\text { partici- } \\
\text { pants } \\
(N=61)\end{array}$ & Planning scale of activity & Sector/area of interest & Selection criteria & Motivation for grouping \\
\hline Farmers & 18 & Local & Community & $\begin{array}{l}\text { Involved in tree crop plan- } \\
\text { tation development, food } \\
\text { crop farming, mangrove } \\
\text { restoration }\end{array}$ & $\begin{array}{l}\text { Implementation of land-use } \\
\text { plans at the landscape } \\
\text { scale }\end{array}$ \\
\hline Landowners & 7 & Local & Community & $\begin{array}{l}\text { Minimum land holding of } \\
20,000 \text { ha }\end{array}$ & \\
\hline NGO professionals & 8 & Local to Regional & $\begin{array}{l}\text { Environment and Devel- } \\
\text { opment }\end{array}$ & $\begin{array}{l}\text { Minimum, } 10 \text { years } \\
\text { practice experience in } \\
\text { the region }\end{array}$ & $\begin{array}{l}\text { Facilitating knowledge } \\
\text { exchange between govern- } \\
\text { ment, private sector and }\end{array}$ \\
\hline Researchers & 10 & Local to Regional & $\begin{array}{l}\text { Coastal Management, } \\
\text { Regional Planning, } \\
\text { Ecology }\end{array}$ & $\begin{array}{l}\text { Minimum, } 10 \text { years } \\
\text { research experience in } \\
\text { the region }\end{array}$ & $\begin{array}{l}\text { community-level actors } \\
\text { in LUP }\end{array}$ \\
\hline \multirow[t]{5}{*}{ Land-use planners } & \multirow[t]{5}{*}{18} & \multirow[t]{5}{*}{ Local to Regional } & Forestry & Regional Forestry Officer & \multirow{5}{*}{$\begin{array}{l}\text { Providing technical input } \\
\text { for the preparation and } \\
\text { approval of land-use plans }\end{array}$} \\
\hline & & & Environmental Protection & Programme Officer & \\
\hline & & & Agriculture & $\begin{array}{l}\text { District Agricultural } \\
\text { Officer }\end{array}$ & \\
\hline & & & $\begin{array}{l}\text { Land-use and Spatial } \\
\text { Planning }\end{array}$ & $\begin{array}{l}\text { Regional/District LUP } \\
\text { officer }\end{array}$ & \\
\hline & & & Development Planning & $\begin{array}{l}\text { District Development } \\
\text { Planning officer }\end{array}$ & \\
\hline
\end{tabular}

list all cultural benefits or practices that are perceived to be important for connecting people to the landscape. Pictures of key landscape features, species and artefacts were provided for orientating their thoughts and stimulating open dialogue on cultural benefits of the landscape. Through free-listing, the LUPAs identified CES supplied by the landscape and performed ranking exercises to prioritize the most relevant CES (see Sect. 3.1). Using this approach, the perspectives of LUPAs, regarding the importance and categorizations of the various benefits provided by the regional landscape were revealed (Infield et al. 2015, p 25). Outcomes of free-listing and prioritization of relevant CES and results of the LULC classification were utilized as inputs to develop the LUP scenarios and for designing the survey questionnaire.

\subsubsection{Development of land-use planning scenarios}

We developed four future alternative LUP scenarios to explore potential increase in supply of relevant CES under given regional environmental conditions. The developed scenario outcomes were compared to the business-as-usual scenario. The scenarios are spatially explicit representations of LULC trends and were developed during a 3-step process. In the first step, visions were articulated by LUPAs. The visioning exercise was informed by LULC trends revealed in the LULC classification, LUPA's knowledge on the drivers of land-use changes in the region and their future land-use preferences. LULC maps, photographs and ortho-rectified images of the landscape were utilized during an open dialogue with the representatives of LUPAs to develop scenario narratives during the second step. The final scenario narratives were derived on the basis of consensus reached through the dialogue process. Due to the unfamiliarity of LUPAs with the concept of ES, we provided additional information throughout the workshops to frame discussions around future alternative LUP scenarios for CES supply. During the final step, the visions and scenario narratives were used to develop spatially explicit representations of future alternative LUP scenarios for CES supply in the study region. This was performed through participatory mapping exercise during which LUPAs used the GISCAME free hand tools. The participatory mapping exercise was facilitated by projecting the 2018 LULC map (baseline situation) on a screen and new landscape features were added on the baseline map on the basis of consensus reached by LUPAs, regarding an optimal representation of alternative future land-use scenarios (see Table 4). Using this approach, the knowledge of the selected LUPAs concerning the objectives of existing plans such as the Western Region Spatial Development Framework (WRSDF) was harnessed to inform scenario development (Inkoom et al. 2017, p 74; Inkoom et al. 2018, p 396).

\subsubsection{Questionnaire survey}

Questionnaire survey was employed to elicit individual LUP actor's perceptions of land-use impacts on the supply 
of relevant CES under the future alternative LUP scenarios and specific regional environmental conditions. The questionnaires were organized in four sections with each section corresponding to a LUP scenario. The evaluation was done as follows: a) on a scale of 1 (very low) to 5 (very high), the relative CES provisioning potential of the eight LULC types; b) on a scale of 1 (very low) to 5 (very high), the probability of conversion from one LULC type to another; and c) on a scale of 1(low) to 3(high), the impact of LULC conversions on the potential supply of CES (Koschke et al. 2012, pp 57-59; Inkoom et al. 2018, pp 396-397). Respondents completed their evaluation simultaneously against given environmental conditions, namely slope, elevation, tidal influence and soil. Environmental attributes are important as they influence land-use changes and land-use decision making in ES-based planning (Canedoli et al. 2017, p 10). For example, along the coast, mangrove forests are restricted in their habitat range due to site characteristics such as topography and tidal influences. Consequently, attribute information that describes tidal influence was applied to the simulated mangrove ecosystem restoration scenario. Finally, respondents provided a confidence rating for their evaluation. Overall, 61 respondents participated in the survey.

\subsection{Impact assessment of land-use planning scenarios}

Likert-based scores from the questionnaire were standardized by expressing the values from 0 (the minimum potential of the LULC type to provide the specific cultural ES) to 100 (the maximum potential of the LULC type to provide the specific cultural ES). Standardization facilitates comparison of ES values assigned to LULC types with the same value unit (Koschke et al. 2012, p 59). The ES values were presented in an assessment matrix which depicts the relationship between LULC types and their capacity for CES supply.

The simulated future alternative LUP scenarios were coupled with the ES assessment matrix in GISCAME and the results displayed as spider charts and tables with values denoting the mean capacity of the region to supply CES. Impacts of LUP scenarios on CES supply were expressed as the difference between the mean CES values of the businessas-usual (BAU) scenario and the simulated land-use scenarios. Synergies were characterized by agreement among LUPAs regarding concurrent increase or decrease in supply of CES, whereas trade-offs depicted increase in one CES with concurrent decrease in the same service according to actors' perceptions (Koo et al 2019, p 162).

Kruskal-Wallis test was conducted using SPSS (v.19) to examine whether perceptions and preferences among the different groups of LUPAs regarding land use changes and environmental conditions (soil, elevation, tidal influence, extent of afforestation) influenced the regional performance to supply CES. The Kruskal-Wallis test is appropriate as it compares the medians between three or more independent groups to determine similarities or differences on a dependent variable measured on an ordinal scale (Jargowsky and Yang 2004, p 260). For this study, farmers/landowners, NGOs/researchers and planners comprised the three independent groups while the dependent variables were their perceptions of, and preferences for, CES supply under specified land use scenarios, LULC conversions and environmental conditions.

\section{Results}

\subsection{Identified relevant cultural ecosystem services}

Relevant CES supplied by the regional landscape are shown in Table 3. Definitions of CES were derived from literature and adapted by LUPAs to fit the socio-cultural context of the study region. Relevant CES were prioritized by LUPAs in the following order: science/education, spiritual, tourism, recreation and health benefits.

\subsection{Future alternative land-use planning scenarios}

The scenario development workshops resulted in the composition of four spatially explicit future alternative land-use scenarios aside the BAU scenario. These comprised mangrove ecosystem restoration; mangrove ecosystem restoration and rubber plantation expansion; road and coastal tourism infrastructure expansion; establishing green network by $10 \%$ and $30 \%$ afforestation as shown in Table 4.

\subsection{Impact assessment of land use scenarios}

\subsubsection{Impact of mangrove ecosystem restoration}

Regarding the scenario for restoration of mangrove ecological processes, LUPAs perceived a potential increase in the regional potential to supply all five relevant CES, which indicated positive synergies between CES according to the preferences of farmers/landowners, NGOs/researchers and planners. However, as shown in Fig. 4 A, B and C, an increase in the potential supply of CES by this scenario was only marginal compared to the BAU scenario. Mangrove forests are adapted to brackish water environments in low lying coastal mudflats. Consequently, unlike other landcover types, mangrove forests are confined to the coastal intertidal zone as shown in Fig. 4; hence, mangrove-related CES and benefits may be less well perceived than CES 
Table 3 Relevant cultural ecosystem services supplied by landscapes in Southwestern Ghana as identified by land-use planning actors

\begin{tabular}{|c|c|c|}
\hline Source of literature & Prioritized CES by LUPAs & Definition \\
\hline MEA 2005, pp 57-59; de Groot 2002, p 396-397 & Science/education & $\begin{array}{l}\text { Opportunities for outdoor learning where observation, experi- } \\
\text { ence and experimentation lead to increased ecological knowl- } \\
\text { edge and enhanced connectedness to nature }\end{array}$ \\
\hline $\begin{array}{l}\text { MEA 2005, pp 57-59; Peh et al.2017, pp } \\
\text { 220-221; de Groot 2002, pp 396-397 }\end{array}$ & Spiritual & $\begin{array}{l}\text { Benefits derived from specific places, features or species within } \\
\text { a natural landscape creating sacred, religious or spiritual } \\
\text { inspiration, feelings and values. Religious rules and taboos. } \\
\text { Links to ancestors, gods or spirit world }\end{array}$ \\
\hline MEA 2005, pp 57-59; de Groot 2002, pp 396-397 & Tourism & $\begin{array}{l}\text { Benefits derived from travel to natural ecosystems for tour- } \\
\text { ism, recreational sports and to view rare species. This often } \\
\text { involves costs incurred through travelling or fee payments to } \\
\text { enjoy the benefits }\end{array}$ \\
\hline MEA 2005, pp 57-59; de Groot 2002, pp 396-397 & Recreation & $\begin{array}{l}\text { Benefits derived from playing in open and public places within } \\
\text { close proximity. This does not involve costs incurred through } \\
\text { travelling or actual fee payments in order to enjoy the benefits }\end{array}$ \\
\hline Infield et al. 2015, p 4 & Health & $\begin{array}{l}\text { Places where people can undertake physical activity and } \\
\text { interact with nature, enabling the restoration, maintenance, } \\
\text { and/or development of emotional, mental and physical health } \\
\text { and well-being. Viewing or being in an environmental setting } \\
\text { that contributes to physical, emotional, mental health and } \\
\text { well-being }\end{array}$ \\
\hline
\end{tabular}

Table 4 Business as usual and future alternative land use planning scenarios for CES supply in Southwestern Ghana

Scenario Description

Business-as-usual (BAU)

Mangrove ecosystem restoration

Mangrove ecosystem restoration and expansion of rubber plantation

Road and coastal tourism infrastructure expansion

Green network
Represents plausible outcomes of relevant CES supply in the region if the current rate of growth in the regional population and associated growing demand for food and livelihood improvements continue. The BAU scenario is presented as current LULC transitions characterized by losses of shrubland vegetation in favor of food crop and plantation agriculture expansion

Explores the potential of the landscape to supply relevant CES if community-driven mangrove restoration programs are implemented as a strategy to minimize degradation of wetland ecosystems. Local demand for mangrove to meet fuel wood needs will drive this future land use scenario while local communities strive to achieve a balance between increasing harvesting pressures on mangroves and maintenance of mangrove ecosystem services. The scenario is presented in the LULC classification as conversions from wetlands to mangroves

Explores the potential of the landscape to supply relevant CES if restoration of diverse and resilient mangrove ecosystems along the southern edges of the landscape is complemented by expansion of rubber plantations on the northern portions of the landscape. Major drivers of this future land use scenario are global voluntary carbon markets and reducing emissions from deforestation and land degradation (REDD+) projects that seek to incentivize large scale mangrove restoration in tropical and sub-tropical environments. In addition, favorable government policies will drive rubber plantation expansion. The scenario is presented in the LULC classification as conversions from wetlands to mangroves and from cropland to rubber plantation

Explores the landscape's potential to supply relevant CES if low-impact and nature-based tourism infrastructure are developed along the coastal stretch, including enhancing commuting to tourism and recreation sites by improving road access. This scenario is characterized by conversion of cropland and shrubland to artificial/bare areas

Explores the potential of the landscape to supply relevant CES, if afforestation of the landscape is achieved at $10 \%$ and $30 \%$, respectively, by planting native trees to connect coastal and upland forest corridors and to serve as migratory routes for wild animals and for protecting biodiversity. In this scenario, shrubland/sparse vegetation in the LULC classification represent native trees suitable for landscape afforestation 
Table 5 Differences in perceptions and preferences for CES supply between groups of land use planning actors on the basis of land-use scenarios, LULC conversions and environmental influences. Significance $=p<0.05 ; d f=$ degrees of freedom; $N=61$

\begin{tabular}{|c|c|c|c|c|c|c|}
\hline Groups of LUPAs & LUP Scenario & LULC conversion & Environmental condition & $\begin{array}{l}H \text { (chi- } \\
\text { square } \\
\text { statistic) }\end{array}$ & $d f$ & $p$ value \\
\hline $\begin{array}{l}\text { Farmers/landowners and } \\
\text { NGOs/researchers }\end{array}$ & Business-as-usual & $\begin{array}{l}\text { Shrubland to artificial/bare } \\
\text { areas }\end{array}$ & Low elevation & 6.94 & 2 & 0.03 \\
\hline $\begin{array}{l}\text { Farmers/landowners and } \\
\text { planners }\end{array}$ & & & Low elevation & 6.94 & 2 & 0.02 \\
\hline $\begin{array}{l}\text { Farmers/landowners and } \\
\text { planners }\end{array}$ & $\begin{array}{l}\text { Road and coastal tourism } \\
\text { infrastructure expansion }\end{array}$ & $\begin{array}{l}\text { Rainfed cropland to artificial/ } \\
\text { bare areas }\end{array}$ & Poorly drained soil & 6.42 & 2 & 0.02 \\
\hline $\begin{array}{l}\text { Farmers/landowners and } \\
\text { planners }\end{array}$ & $\begin{array}{l}\text { Mangrove ecosystem } \\
\text { restoration and rubber } \\
\text { expansion }\end{array}$ & $\begin{array}{l}\text { Rainfed cropland to rubber } \\
\text { plantation }\end{array}$ & Well drained soil & 6.61 & 2 & 0.01 \\
\hline $\begin{array}{l}\text { Farmers/landowners and } \\
\text { planners }\end{array}$ & Green network & Rainfed cropland to forest & $10 \%$ afforestation & 9.44 & 2 & 0.005 \\
\hline
\end{tabular}
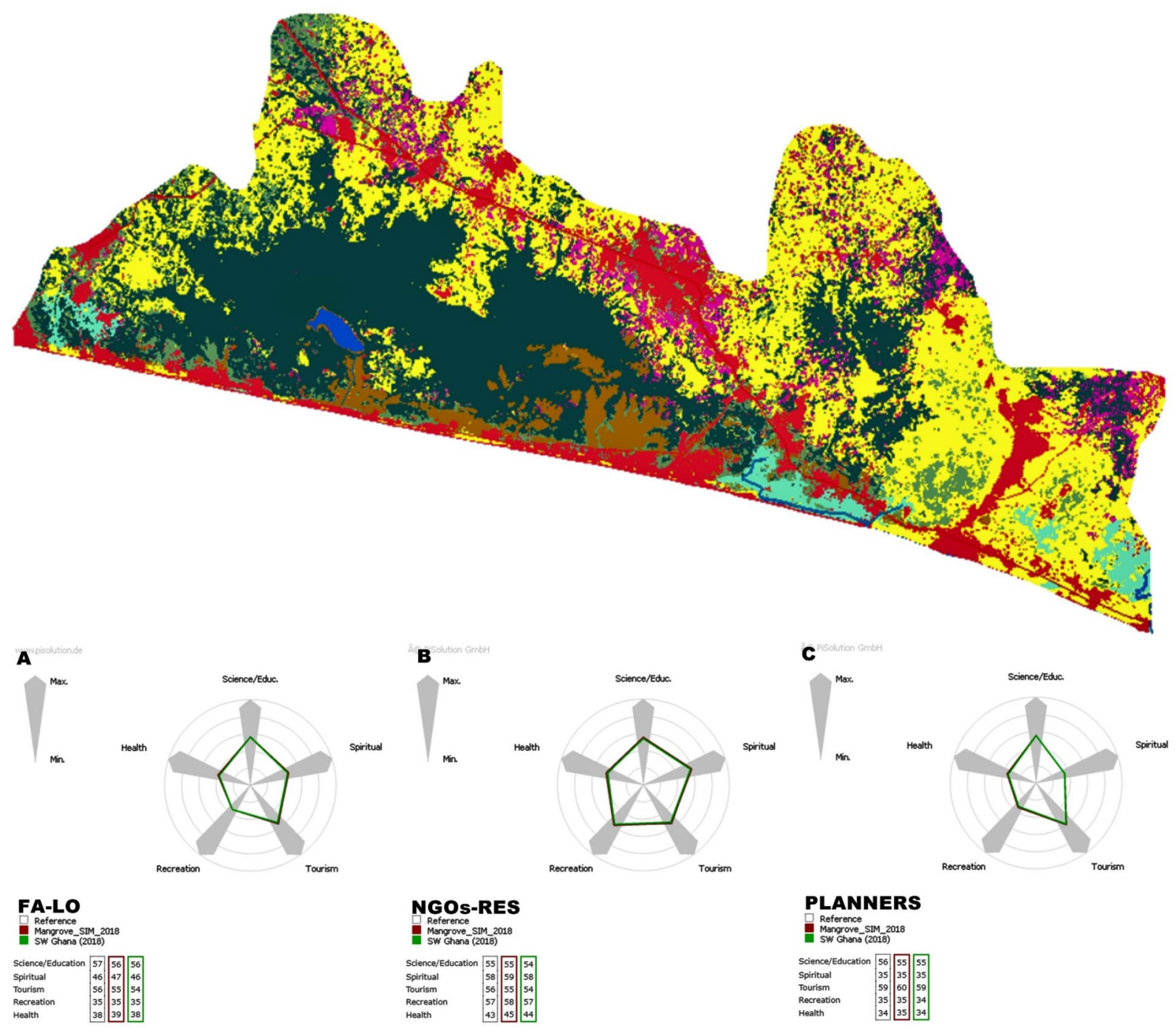

Fig. 4 Spider charts displaying assessment results of the regional potential to supply cultural ecosystem services influenced by mangrove ecosystem restoration scenario. A results from farmers/landowners (B) results from NGO professionals and researchers $(\mathbf{C})$ results from planners 


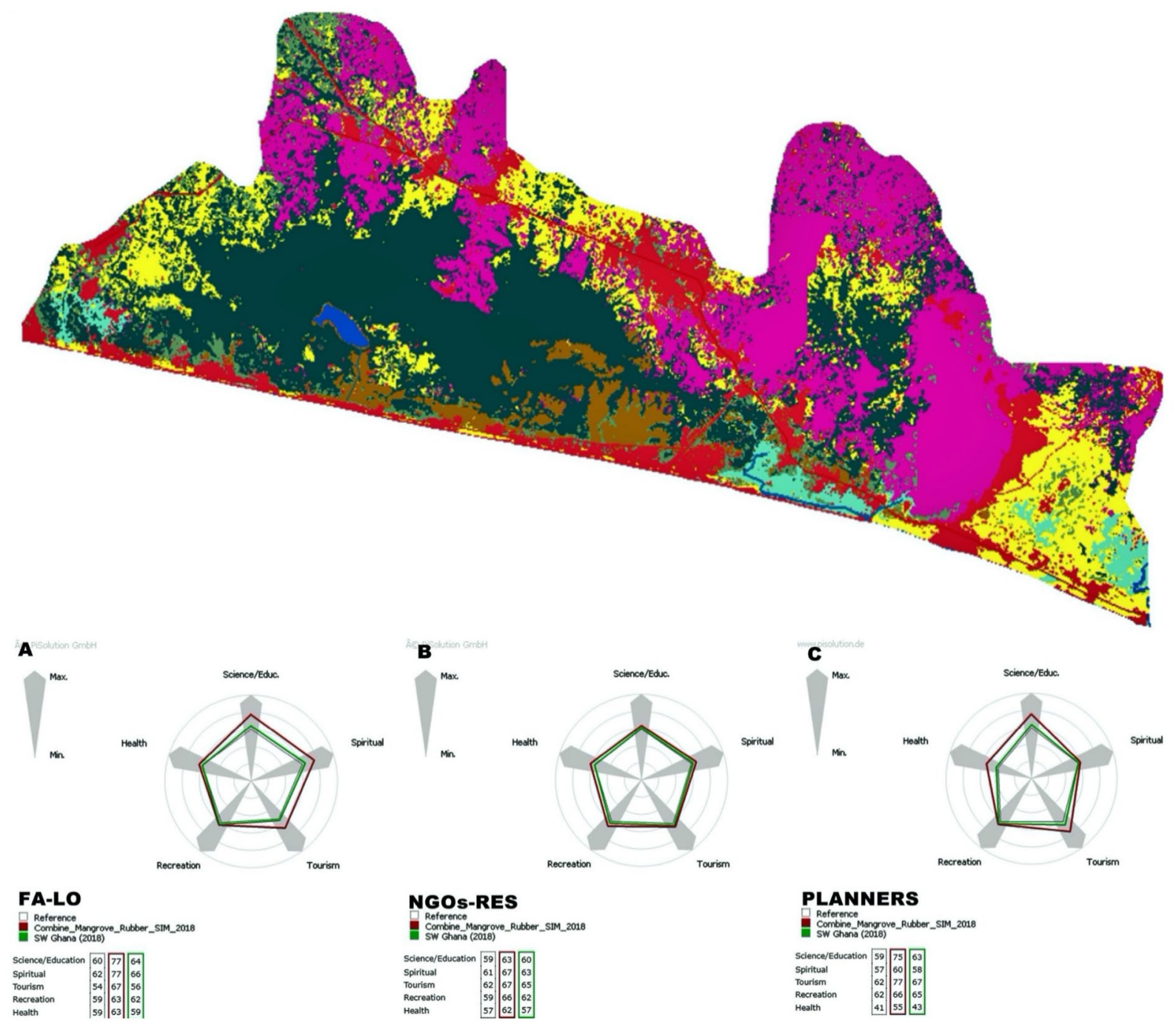

Fig. 5 Spider charts displaying assessment results of regional potential to supply cultural ecosystem services based on mangrove ecosystem restoration and rubber expansion scenario. A results from farm-

supplied by other land-cover types with larger geographical range (Table 5).

\subsubsection{Impact of mangrove ecosystem restoration and expansion of rubber plantations}

A combined mangrove ecosystem restoration and rubber plantations expansion scenario showed an increase in the regional potential to supply science/education, spiritual, tourism, recreation and health benefits. However, as shown in Fig. 5B, NGOs/researchers perceived marginal increases in the regional potential to supply all CES compared to the BAU scenario. As depicted in Fig. 5A, the regional potential to supply science/education and tourism benefits as well as to motivate nature-based spiritual experiences were highly perceived by farmers/landowners. On the contrary, the ers/landowners (B) results from NGO professionals and researchers (C) results from planners

supply of recreational and health benefits was perceived to a lesser extent by farmers/landowners. Planners also perceived a relatively high regional potential to supply tourism and science benefits (see Fig. 5C). However, contrary to farmers/ landowners, planners considered a high regional potential to supply health benefits as shown in Fig. 5C. This suggests trade-offs in the perceptions between farmers/landowners and planners regarding the regional potential to supply health benefits in the context of combined mangrove ecosystem restoration and rubber plantation expansion scenario.

\subsubsection{Impact of road and coastal tourism infrastructure expansion}

This scenario is derived from a market-oriented scenario archetype, which is characterized by the expansion of the $\mathrm{N} 1$ 

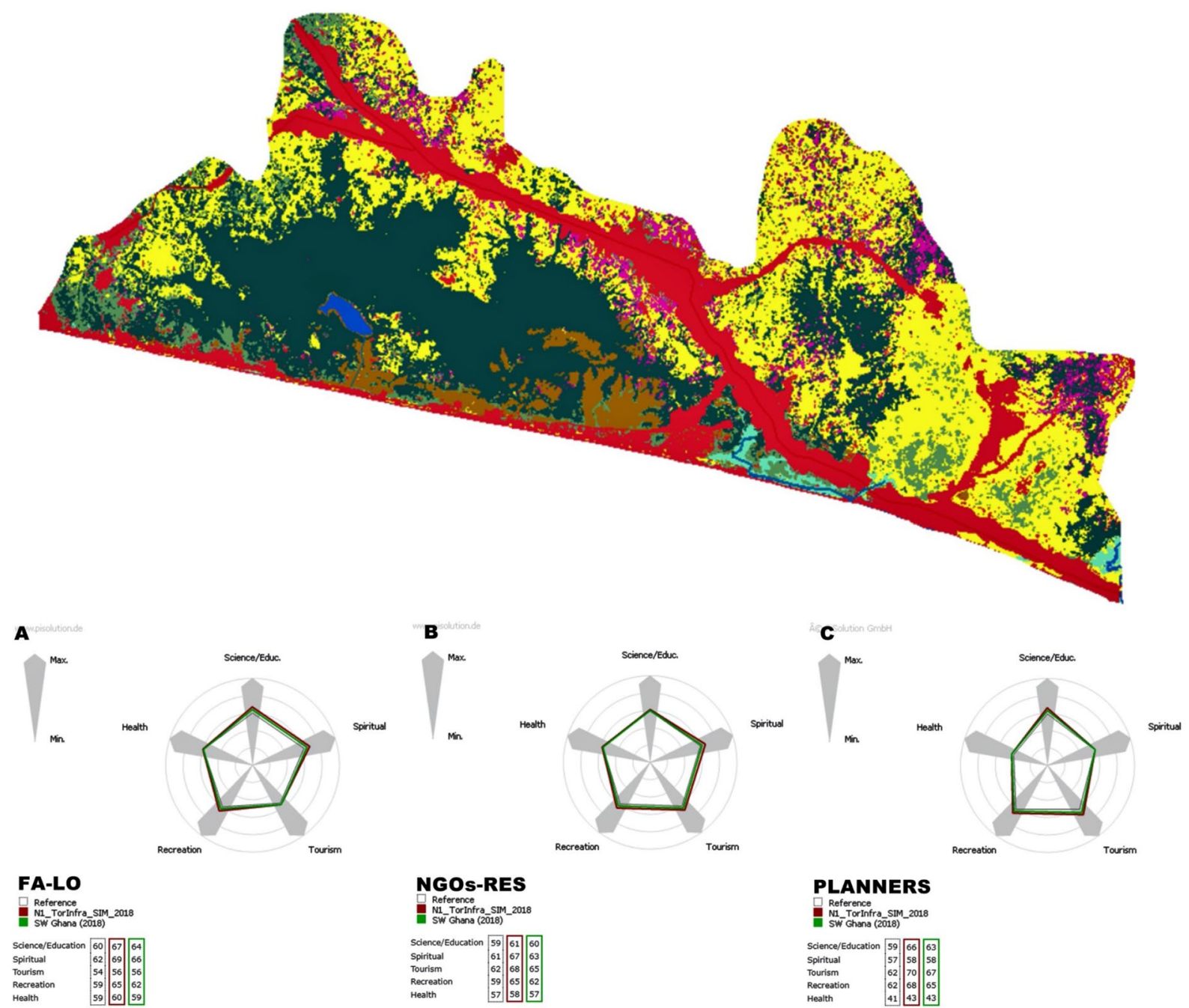

Fig. 6 Spider charts displaying assessment results of regional potential to supply cultural ecosystem services based on road and coastal tourism infrastructure expansion scenario. A results from farmers/

highway, connecting road networks and tourism infrastructure dotting the coastline. As shown in Fig. 6A, all LUPAs perceived an increase in the regional potential to supply spiritual, science/education, health, tourism and recreational benefits. Nonetheless, farmers/landowners perceived only marginal increase in potential supply of tourism benefits compared to the BAU scenario. On the other hand, NGOs/ researchers and planners perceived a relatively high regional potential to supply tourism benefits (see Fig. 6B and C). This suggests positive synergies between NGOs/researchers and planners regarding the supply of tourism benefits under this scenario. landowners $(\mathbf{B})$ results from NGO professionals and researchers $(\mathbf{C})$ results from planners

\subsubsection{Impact of establishing green network by afforestation}

The visualization of green network scenario outcomes illustrated similarities but also marked differences in how LUPAs perceived a future green network situation in the region. Farmers and land-owners, preferred a green network which traverses the edges of coastal wetlands and connects with upland forests as depicted in Fig. 7A. On the other hand, NGOs, researchers and planners were in favor of creating a green network along river courses to connect with upland forests as shown in Figs. 8 and 9, respectively. A major contrast between other LUPAs and planners is the preference by the latter for planting native vegetation along trunk and arterial roads as illustrated by Fig. 9. This viewpoint was supported by their argument that along road corridors, native 

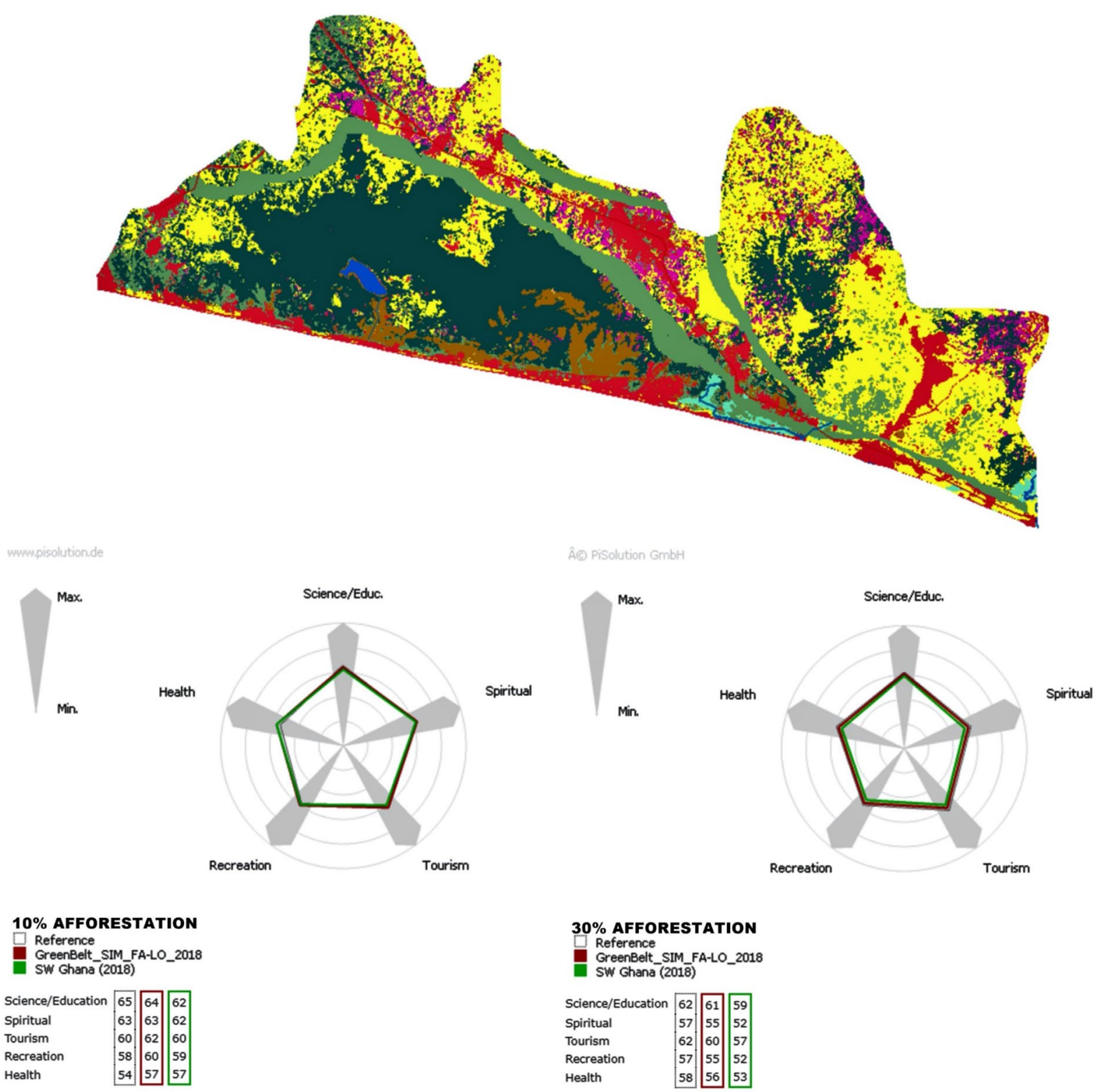

Fig. 7 Spider charts displaying assessment results of regional potential to supply cultural ecosystem services based on establishing green network by $10 \%$ and $30 \%$ afforestation according to farmers/landowners' preferences

trees serve the purpose of implementing additional planning restrictions against settlement and other infrastructure encroachment on land earmarked for future road expansion.

Considering the preferences of planners, establishing green network by $30 \%$ afforestation increased regional potential to provide recreation and tourism benefits while at $10 \%$ afforestation, recreation benefits were maintained and tourism services decreased compared to the BAU scenario as shown in Fig. 9. Nonetheless, 30\% afforestation was associated with trade-offs in the preferences between planners, NGOs/researchers and farmers/landowners regarding the potential of the region to provide tourism and recreation benefits. At $10 \%$ afforestation, nature-based spiritual experiences decreased compared to the BAU scenario whereas at $30 \%$ afforestation, nature-based spiritual experiences were maintained considering the preferences of all LUPAs (see Fig. 7, 8 and 9).

This implies regional potential to provide nature-based spiritual experiences will not be enhanced by implementing future green network land-use scenarios as negative synergies are inherent in such a land-use decision. Regional performance regarding science/education benefits at $10 \%$ 

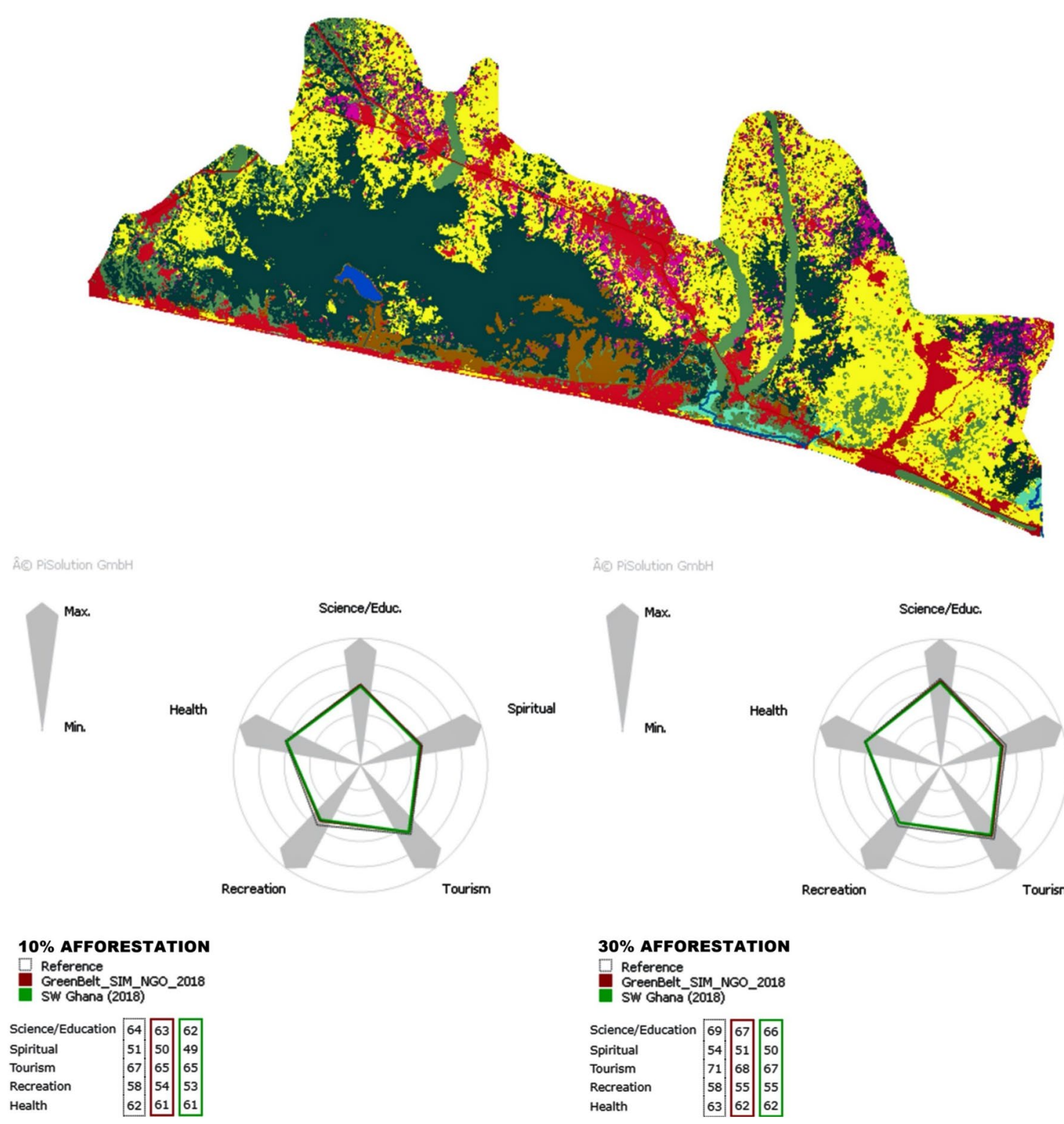

Fig. 8 Spider charts displaying assessment results of regional potential to supply cultural ecosystem services based on establishing green network by $10 \%$ and $30 \%$ afforestation according to NGOs/researchers' preferences

afforestation also decreased according to the preferences of farmers/landowners and NGOs/researchers compared to the BAU scenario, depicting negative synergies. This contrasts with an increase in the regional potential to supply science/ education services at $10 \%$ afforestation, considering preferences of planners.

\subsection{Comparative assessment of actors' preferences and perceptions}

Kruskal-Wallis test was conducted using SPSS v19 to examine whether perceptions and preferences among different groups of LUPAs regarding land use changes and environmental conditions (soil, elevation, tidal influence, extent of afforestation) influenced the regional performance to supply CES. No significant difference was found among the LUPAs $(H(2)=1.33 ; p=0.51)$ regarding their perceptions on CES supply in the mangrove ecosystem restoration scenario under 

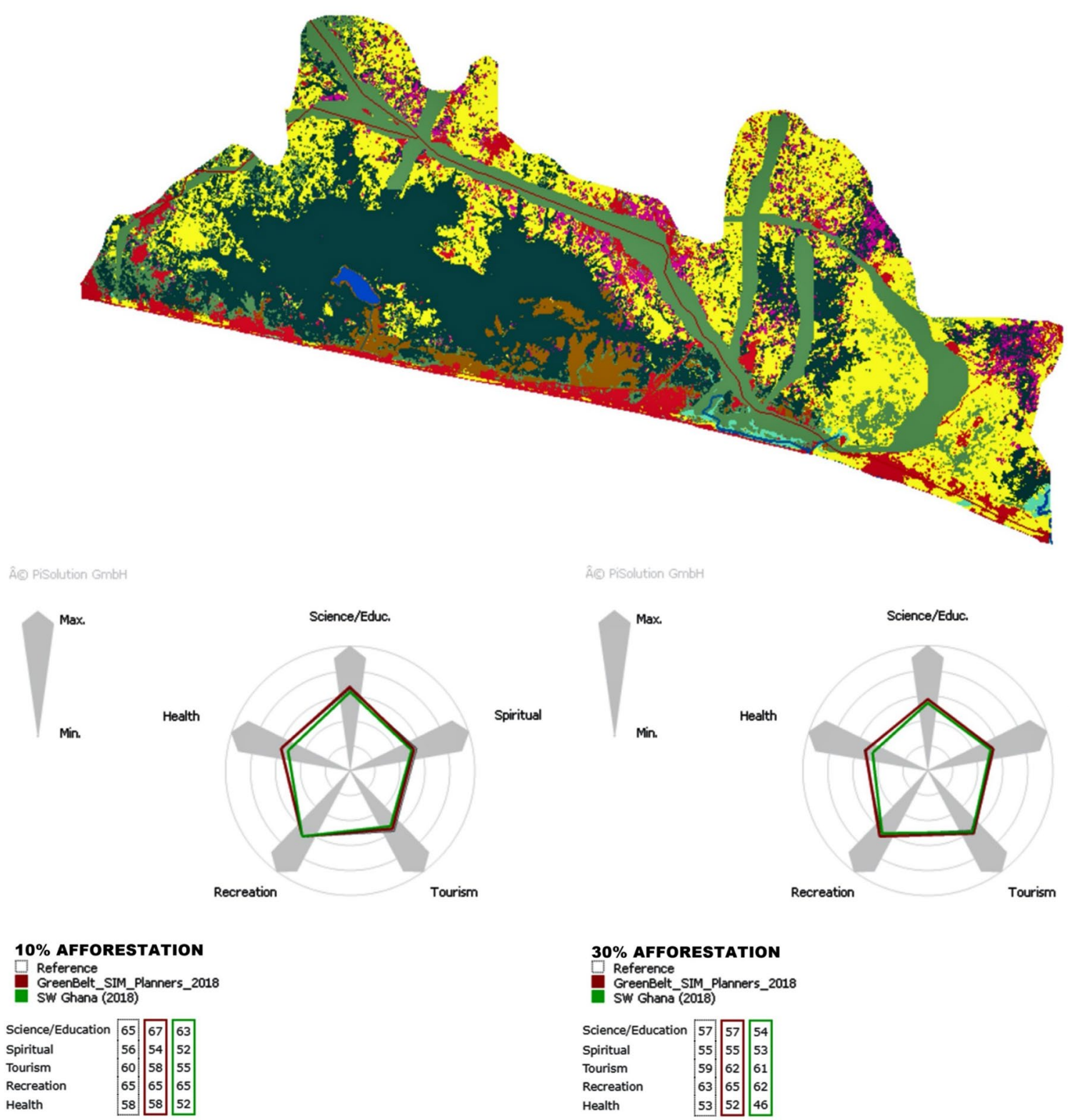

Fig. 9 Spider charts displaying assessment results of regional potential to supply cultural ecosystem services based on establishing green network by $10 \%$ and $30 \%$ afforestation according to planners' preferences

conditions of tidal influence. However, considering the BAU scenario, differences in perceptions of CES supply were significant between farmers/landowners and NGOs/researchers $(H(2)=6.94 ; p=0.03)$ and between farmers/landowners and planners $(H(2)=6.94 ; p=0.02)$. Such differences relate to shrubland conversions to artificial/bare areas at low elevation. Similarly, for scenarios that were market-driven (road and coastal tourism infrastructure expansion; mangrove ecosystem restoration and rubber plantation expansion), significant differences in perceptions of CES supply were evident between farmers and planners relative to rainfed cropland conversions to artificial/bare areas under poorly drained soil conditions $(H(2)=6.42 ; p=0.02)$ and to rubber plantation given welldrained soil conditions $(H(2)=6.61 ; p=0.01)$. Finally, considering a green network scenario, significant differences in preferences for CES supplies were evident between farmers/ 
landowners and planners and this pertains to $10 \%$ afforestation and conversion from rainfed cropland to forests $(H(2)=9.44$; $p=0.005)$.

\section{Discussions}

\subsection{Perceptions and preferences of land-use planning actors for cultural ecosystem services supply}

CES are supplied through human perceptions of ecosystem benefits. And often, such benefits are shaped by individual and societal value systems (Jones et al. 2020, pp 123-137). Thus, quantification of CES requires citizen participation in order to provide a basis for their uptake in land-use policy (García-Díez et al. 2020, p 2). Our findings show that LUPAs in the coastal region envision a mix of future landuse configurations as plausible pathways towards deriving non-material benefits from coastal landscapes. From the set of future land-use scenarios, mangrove ecosystem restoration and green network scenarios directly support implementation of regional spatial policies on environmental protection as articulated in the Western Regional Spatial Development Framework (WRSDF). The WRSDF puts forward policies for protection of mangroves, forests and wetlands and proposes the creation of wildlife corridors on the landscape. Ironically, the study landscape is simultaneously designated as the area where heavy industrial activities of the oil and gas industry will be confined. This will potentially create tensions between on the one hand, national and regional economic development aspirations, and on the other, local scale desires for CES supply.

In this context, scenarios for CES supply provide useful entry points for improving socio-ecological practice by government planning officials, farmers, landowners, NGOs and researchers through harmonizing development aspirations and natural resources management in the planning, restoration, conservation and management of landscapes. Through the planning process, government planning officials define and direct the allocation of space for land uses. This provides the basis for landowners to decide which land areas to set aside for preserving and protecting landscape CES. Similarly, with the desired planning framework established, landowners are better able to decide where lucrative economic uses of land will be confined while farmers can identify areas to integrate landscape conservation practices into arable farming. Trends and changes in CES supply thresholds will have to be monitored by researchers and practitioners in environmental NGOs and feedback provided to harmonize economic development and landscape conservation.

Besides, land-use scenarios were linked by LUPAs to drivers of LULC changes (e.g., harvesting pressures on mangrove forests, expansion of plantation agriculture, coastal infrastructure development) and environmental conditions that inhibit the potential of the coastal landscape to supply CES. Previous research on land-use scenarios for ecosystem services provisioning in Northern Ghana incorporated local knowledge of threats to ecosystem functions as well as environmental influences on the regional performance to supply ecosystem services (see Inkoom et al. 2018, pp 393-408; Koo et al. 2018, pp 1-21). Similarly, in the reference landscape, elevation, soil conditions, tidal influence and extent of afforestation were addressed as important environmental variables that limit the freedom of LULC changes and related supply of CES. For instance, in the road and coastal tourism infrastructure expansion scenario, land-use changes from cropland to artificial/bare areas were highly perceived for their supply of tourism benefits. In the context of this scenario, conversions to artificial/bare areas signifies development of coastal tourism facilities and related infrastructure which has a positive effect on supply of tourism benefits.

This finding contrasts other studies which found coastal development to have a negative effect on the provision of CES by coastal and marine areas (Fletcher et al. 2014, p 159). Nonetheless, by emphasizing prevailing soil conditions which influence land-use conversion decisions in the road and coastal tourism infrastructure expansion scenario, this study highlights the importance of environmental variables in site-based assessments of CES provisioning. This is also consistent with the results of previous CES research which found that environmental factors have a strong effect on the generation of cultural benefits such as outdoor recreation, aesthetic enjoyment and sense of place (García-Díez et al 2020, pp 6-7). On the contrary, participatory scenariobased studies that overlooked the effect of environmental conditions in the development of plausible land-use futures for CES supply, missed the opportunity to incorporate the dynamics of environmental influences in scenario outcomes (see Plieninger et al. 2013, pp 1-16).

Green spaces have been highly valued for their multiple ES provisioning (Dickinson and Hobbs 2017, 186). However, findings of this study present that an increase in the extent of green spaces by afforestation does not necessarily lead to higher preference values for supply of benefits related to science/education and nature-based spiritual experiences (see sub-Sect. 3.3.4). This is particularly noteworthy as science/education and nature-based spiritual experiences recorded lower preference values at $10 \%$ and $30 \%$ afforestation (green network scenarios) compared to the BAU land-use scenario. Located within Ghana's forest zone, the landscapes in the study region possess relatively high degree of naturalness associated with the BAU scenario. This, perhaps, contributed to undervaluation by LUPAs of the potential of green network by afforestation to supply CES in the 
region; implying that creation of additional green spaces will unlikely result in significant improvements in the supply of relevant CES by the regional landscape (see Figs. 7, 8 and 9).

In line with global landscape restoration targets, the government of Ghana has pledged to restore two million hectares of its lost and degraded forest landscapes by 2030 (Foli 2018, pp 1-4). Among other landscapes, southwestern Ghana is targeted for such restoration efforts. This finding is instructive for the national quest for bringing deforested and degraded landscapes into restoration. This is because outcomes of the green network scenario point to pragmatic challenges in achieving restoration success considering this landscape. Besides, the goal of government's landscape restoration policy initiative is at variance with LUPAs preferences for green network by afforestation. Consequently, local actors' acceptance of government's overarching landscape restoration policy remains a work in progress and thus, calls for extensive participation of LUPAs and more transparency in landscape restoration decision- making processes in the region.

\subsection{Synergies and trade-offs in the supply of cultural ecosystem services}

According to the assessment and validation results, potential synergies between CES explored in the present study (science/education, tourism, spiritual, health and recreation) are anticipated by all land-use scenarios, except the green network scenario. Thus, the implementation of these landuse scenarios can be considered to enhance the supply of the referenced CES in this coastal landscape. This finding is in agreement with evidence pointing to synergistic relations between CES in coastal areas (Rodrigues et al. 2017, pp 18-19).

Nonetheless, striking intra-scenario tradeoffs were revealed regarding the supply of tourism benefits by the road and coastal tourism infrastructure expansion scenario (see sub-Sect. 3.3.3). This provokes perceptual conflicts in the potential supply of tourism benefits between farmers/landowners and planners on the one hand, and between farmers/ land owners and NGOs/researchers on the other. Similar tendencies towards perceptual conflicts between farmers/ landowners and planners and between farmers/land owners and NGOs/researchers also arise from the observed tradeoffs in the supply of health benefits in the mangrove ecosystem restoration and rubber plantation expansion scenario. The apparent conflicting viewpoints reflect inherent divergence in stakeholder interests in land use planning, including divergent stakeholder priorities for landscapes CES supply. This finding parallels with previous research that found mismatches in the perceptions of CES supply between land-use decision makers and land users (Canedoli et al. 2017, p 13).
In the study region, regional and municipal land-use planners are more likely to decide in favor of market-oriented LUP scenarios (road and coastal tourism infrastructure expansion; mangrove ecosystem restoration and rubber plantation expansion) and of the supply of tourism benefits from such scenarios. Such decision-making orientation becomes even more pronounced, considering areas of the landscape where soil conditions are poor and therefore present limited opportunities for arable farming. Importantly, tourism benefits derived from coastal landscapes constitutes an important source of revenue for coastal municipalities and also create opportunities for economic development in coastal communities. On the other hand, farmers and land owners in the study region are more likely to disfavor tourism benefits but rather support decisions that supply more health benefits from market-oriented LUP scenarios. Perhaps, the longstanding land stewardship ethic of farmers and landowners in the study region underlies such decision-making orientation. Generally, all categories of LUPAs (farmers, landowners, researchers, NGO professionals and land-use planners) in the study region will unlikely support decisions that favor establishing green networks for supplying nature-based spiritual experiences and science/education benefits. However, NGOs/researchers and planners are likely to decide in favor of establishing green networks for the supply of tourism and recreational benefits.

\subsection{Limitations of the applied approaches}

To be useful for land-use decision-making, valuation of CES should occur at a fine enough spatial scale to facilitate identification and designation of specific zones of CES supply (Canedoli et al. 2017, pp 11-13). In this light, our study suffers from some limitations. The first limitation relates to the difficulty to address the nuances of spatial differences in CES provision at local scale due to the use of coarse LULC data. For instance, the broad LULC categories used for the study concealed other LULC sub-classes that are valued by society for their non-material benefits. The second limitation is presented by the fact that artificial/bare areas encompass non-natural built-up infrastructures that do not necessarily offer nature-based contributions to society and thus careful interpretation on the perceptions of, and preferences for, such areas as sources of CES supply is required. Third, while land-use planning regulations influence the CES supply potential of the landscape, the study overlooked this dimension in the impact assessment of land use scenarios. Fourth, while grouping of LUPAs was convenient for the study design, this might have introduced bias, particularly, in the development and visualization of the green network scenarios. Furthermore, oil and gas private sector actors were overlooked in conducting the workshops, despite their positions as key land users with vested economic interests 
on matters related to land-use and land management. However, there were concerns that power asymmetries between them and farmers could have jeopardized the transparency and openness that characterized the workshops. The foregoing limitations of the study were, however, partly addressed by providing pictures to illustrate examples of peculiar landscape features occurring in the broad LULC classes during the workshops and surveys. Detailed local knowledge of LUPAs on the study landscape also contributed to mitigating the effect of coarse LULC data on the study outcomes. Besides, this approach enhanced bottomup planning processes by bridging communication gaps and improving knowledge exchange among different LUPAs at the regional, district and local levels. Involving a diverse group of LUPAs generated rich discussions that informed scenario development, thus increasing the validity, reliability and applicability of the designed scenarios (Plieninger et al. 2013, pp 12-13). Finally, the approach to scenario development enabled examination of coherence of the scenarios from different LUPAs perspectives (Keeler 2014, pp 20-53).

\section{Conclusions and outlook}

The assessment and integration of CES in landscape planning and management still remain elusive mainly because this direction of research lacks a common methodological framework for CES assessments. This study demonstrated that spatially explicit land use scenarios that incorporate place-based values, perceptions and preferences for CES, provide a useful basis for integrating CES considerations in LUP and decision-making. This study aimed at participatory development and validation of alternative land-use scenarios and examination of the resulting scenario impacts on CES supply. Utilization of biophysical data coupled with pictures and visualization tools in GISCAME during the actor workshops fostered communication and actor awareness of otherwise difficult ES concepts.

The results of the study indicate that in the coastal landscape of Southwestern Ghana, values, perceptions and preferences of LUPAs underpin socio-ecological interactions aimed at maintaining and enhancing CES supply. In addition, it revealed that future supply of CES is characterized by an interplay between multiple and diverse perspectives about plausible land-use futures. Perceptions of and preferences for CES align with land-use visions related to afforestation, tourism, infrastructure development and agriculture expansion. In such a context where an array and diversity of individual and societal values exist, effective negotiation and facilitation are essential for harnessing and optimizing land-use planning for CES supply.

The process for integrating ES into land use and spatial planning processes in Ghana has been proposed by Inkoom et al. (2017, p 77). This study provides a practical entry point to realize and implement such integration at the landscape scale. A hierarchical spatial planning approach of Ghana mandates the preparation of structure and local plans at the lower tiers. Existence of the Western Region Spatial Development Framework (WRSDF) which covers the study region can serve as an anchor for landscape scale integration of CES considerations as part of structure and local plan preparation. The visions of LUPAs presented in this study could be the starting points for consensus building and validation of perceptions and preferences for CES supply among different actor groups such as public officials, civil society representatives, traditional authorities, academics and private sector entities. The study demonstrates that extensive dialogue with actors, notably landowners and farmers, to better understand motivations and preferences for landscape restoration as well as to develop the right incentives to enable landscape restoration success will be required. Finally, the study provides the basis for re-thinking landscape restoration approaches, as this will influence achievement or otherwise, of landscape restoration targets at both the national and global levels.

Supplementary Information The online version contains supplementary material available at https://doi.org/10.1007/s42532-021-00090-7.

Acknowledgements We acknowledge the efforts of Justice Mensah and Daniel Nii Doku Nortey for assisting with workshop facilitation and field data gathering. We are thankful to Destina Samani, USFS Western Africa Regional Specialist for the project management support to Hen Mpoano. Finally, we are immensely grateful to all workshop participants for their invaluable time and knowledge shared without which this research will not be possible.

Authors' contributions Stephen Kankam conceptualized the research, collected and analyzed the data and drafted the article; Justice Nana Inkoom supported with conceptualizing the article and provided review comments; Hongmi Koo provided review comments and Christine Fürst supervised the research and commented on the final draft manuscript.

Funding Open Access funding enabled and organized by Projekt DEAL. We acknowledge the contribution of the United States Forest Service (USFS) and the United States Agency for International Development (USAID) for providing funding support to Hen Mpoano (www. henmpoano.org) under the project, "Enhancing Greater Amanzule Wetland Conservation through Mangrove Ecosystem Monitoring and Management Planning", within which this research data was gathered.

Availability of data and material All data derived through this study will be made available upon request.

\section{Declarations}

Conflict of interests No conflict of interest to be declared.

Open Access This article is licensed under a Creative Commons Attribution 4.0 International License, which permits use, sharing, 
adaptation, distribution and reproduction in any medium or format, as long as you give appropriate credit to the original author(s) and the source, provide a link to the Creative Commons licence, and indicate if changes were made. The images or other third party material in this article are included in the article's Creative Commons licence, unless indicated otherwise in a credit line to the material. If material is not included in the article's Creative Commons licence and your intended use is not permitted by statutory regulation or exceeds the permitted use, you will need to obtain permission directly from the copyright holder. To view a copy of this licence, visit http://creativecommons. org/licenses/by/4.0/.

\section{References}

Acheampong RA (2019) Local-level spatial planning and development management. The Urban Book Series, Switzerland. https://doi. org/10.1007/978-3-030-02011-8 6

Agyemang FSK, Amedzro KK, Silva E (2017) The emergence of cityregions and their implications for contemporary spatial governance: evidence from Ghana. Cities 71(July):70-79. https://doi.org/ 10.1016/j.cities.2017.07.009

Ajonina G (2011) Rapid assessment of mangrove status to assess potential for payment for ecosystem services in Amanzule in the western region of Ghana. USAID Integrated Coastal and Fisheries Governance Program for the Western Region of Ghana. Available via https://henmpoano.org/wp-content/uploads/2016/06/HM_ Rapid-Assesment-of-Mangrove-Status-for-PES.pdf. Accessed 20 Apr 2021

Amoakoh AO, Aplin P, Awuah KT, Delgado-fernandez I, Moses C, Alonso CP, Kankam S, Mensah JC (2021) Testing the contribution of multi-source remote sensing features for random forest classification of the Greater Amanzule tropical peatland. Sensors 21:3399. https://doi.org/10.3390/s21103399

Blicharska M, Smithers RJ, Hedblom M, Hedenås H, Mikusiński G, Pedersen E, Sandström P, Svensson J (2017) Shades of grey challenge practical application of the cultural ecosystem services concept. Ecosyst Serv 23:55-70. https://doi.org/10.1016/j.ecoser. 2016.11.014

Brown G, Nora F (2015) Empirical PPGIS/PGIS mapping of ecosystem services: a review and evaluation. Ecosyst Serv 13:119-133. https://doi.org/10.1016/j.ecoser.2014.10.007

Brown G, Vera H (2017) An empirical analysis of cultural ecosystem values in coastal landscapes. Ocean Coast Manag 142:49-60. https://doi.org/10.1016/j.ocecoaman.2017.03.019

Brown G, Pullar D, Hausner VH (2016) An empirical evaluation of spatial value transfer methods for identifying cultural ecosystem services. Ecol Ind 69:1-11. https://doi.org/10.1016/j.ecolind. 2016.03.053

Brown G, Weber D (2013) Using public participation GIS (PPGIS) on the Geoweb to monitor tourism development preferences. J Sustain Tour 21(2):192-211. https://doi.org/10.1080/09669582. 2012.693501

Burkhard B, Kroll F, Müller F, Windhorst W (2009) Landscapes' capacities to provide ecosystem services - a concept for landcover based assessments. Landscape Online 15(1):1-22. https:// doi.org/10.3097/LO.200915

Burkhard B, Maes J (eds) (2017) Mapping ecosystem services. Pensoft Publishers, Sofia

Canedoli C, Bullock C, Collier MJ, Joyce D, Padoa-Schioppa E (2017) Public participatory mapping of cultural ecosystem services: citizen perception and park management in the Parco Nord of Milan (Italy). Sustainability 9:891. https://doi.org/10.3390/su906 0891

Critical Ecosystem Partnership Facility (CEPF) (2000) Ecosystem profile: Upper Guinean forest ecosystem of the Guinean Forests of West Africa biodiversity hotspot. Available via https://www.cepf. net/sites/default/files/final.guineanforests.upperguineanforest.ep_. pdf. Accessed 14 May 2021

Chan KMA, Guerry AD, Balvanera P, Klain S, Satterfield T, Basurto $\mathrm{X}$, Bostrom A et al (2012a) Where are cultural and social in ecosystem services? A framework for constructive engagement. Bioscience 62(8):744-756. https://doi.org/10.1525/bio.2012.62.8.7

Chan KMA, Satterfield T, Goldstein J (2012b) Rethinking ecosystem services to better address and navigate cultural values. Ecol Econ 74:8-18. https://doi.org/10.1016/j.ecolecon.2011.11.011

Coastal Resources Center (2010) Hen Mpoano Our Coast, Our Future: Building capacity for adapting to a rapidly changing coastal zone. Available via https://www.crc.uri.edu/download/GH2009COM0 02_508_REVISED1202.pdf. Accessed 18 Mar 2021

Daniel TC, Muhar A, Arnberger A, Aznar O, Boyd JW, Chan KMA, Costanza R et al (2012) Contributions of cultural services to the ecosystem services agenda. Proc Natl Acad Sci USA 109(23):8812-8819. https://doi.org/10.1073/pnas.1114773109

Daniels T, Chan JKH, Kankam S, Murphy M, Day D, Fürst C, Inkoom JN, Koo H (2021) Four shareworthy SEPR scenario ideas. Socio-Ecol Pract Res 3:9-15. https://doi.org/10.1007/ s42532-020-00072-1

Dickinson DC, Hobbs RJ (2017) Cultural ecosystem services: characteristics, challenges and lessons for urban green space research. Ecosyst Serv 25:179-194. https://doi.org/10.1016/j.ecoser.2017. 04.014

Ellis EC, Pascual U, Mertz O (2019) Ecosystem services and nature's contribution to people: negotiating diverse values and trade-offs in land systems. Curr Opin Environ Sustain 38:86-94. https:// doi.org/10.1016/j.cosust.2019.05.001

Fletcher R, Baulcomb C, Hall C, Hussain S (2014) Revealing marine cultural ecosystem services in the Black Sea. Mar Policy 50:151-161. https://doi.org/10.1016/j.marpol.2014.05.001

Foli EG (2018) Reshaping the terrain: Forest landscape restoration efforts in Ghana. http://www.cifor.org/publications/pdf_files/ factsheet/6986-GLF_Factsheet.pdf

Fürst C, König H, Pietzsch K, Ende HP, Makeschin F (2010) Pimp your landscape - a generic approach for integrating regional stakeholder needs into land use planning. Ecol Soc. https://doi. org/10.5751/ES-03392-150334

Fürst C, Pietzsch K, Witt A, Frank S, Koschke L, Makeschin F (2012) How to better consider sectoral planning information in regional planning: example afforestation and forest conversion. J Environ Plan Manage 55(7):855-883. https://doi.org/10.1080/ 09640568.2011.630067

García-Díez V, García-Llorente M, González JA (2020) Participatory mapping of cultural ecosystem services in Madrid: insights for landscape planning". Land. https://doi.org/10.3390/LAND9 080244

García-Llorente M, Martín-López B, Iniesta-Arandia A, LópezSantiago CA, Aguilera PA, Carlos M (2012) The role of multifunctionality in social preferences toward semi-arid rural landscapes: an ecosystem service approach. Environ Sci Policy 19-20:136-146. https://doi.org/10.1016/j.envsci.2012.01.006

Di Gregorio A, Jansen LJM (2000) Land Cover Classification System (LCCS): classification concepts and user manual. FAO Rome. http://www.fao.org/3/x0596e/x0596e00.htm 
De Groot RS, Alkemade R, Braat L, Hein L, Willemen L (2010) Challenges in Integrating the concept of ecosystem services and values in landscape planning, management and decision making. Ecol Complex 7(3):260-272. https://doi.org/10.1016/j. ecocom.2009.10.006

De Groot RS, Wilson MA, Boumans RMJ (2002) A typology for the classification, description and valuation of ecosystem functions, goods and services. Ecol Econ 41(3):393-408. https://doi.org/ 10.1016/S0921-8009(02)00089-7

Haines-Young R, Potschin M (2013) Common international classification of ecosystem services(CICES): Consultation onVersion 4, AugustDecember 2012. EEA Framework ContractNo EEA/IEA/09/003. Downloaded at https://www.cices.eu and spread sheet

Infield MS, Jones M, Anthem H (2015) Guidance for the rapid assessment of cultural ecosystem services. Oryx 50(1):13

Inkoom JN, Frank S, Fürst C (2017) Challenges and opportunities of ecosystem service integration into land use planning in West Africa-An implementation framework. Int J Biodiver Sci Ecosyst Serv Manag 13(2):67-81. https://doi.org/10.1080/21513 732.2017.1296494

Inkoom JN, Frank S, Greve K, Fürst C (2018) A framework to assess landscape structural capacity to provide regulating ecosystem services in West Africa. J Environ Manag 209:393-408. https:// doi.org/10.1016/j.jenvman.2017.12.027

IPBES (2018) The regional assessment report on biodiversity and ecosystem services for Africa of the Intergovernmental SciencePolicy Platform on Biodiversity and Ecosystem Services. In: Archer E, Dziba L, Mulongoy K J, Maoela MA, Walters M (eds) Secretariat of the intergovernmental science-policy platform on biodiversity and ecosystem services, Bonn, Germany

Jargowsky PA, Rebecca Y (2004) Descriptive and inferential statistics. Encyclopedia Soc Measure. https://doi.org/10.1016/B0-12369398-5/00145-6

Jones L, Holland RA, Ball J, Sykes T, Taylor G, Ingwall-King L, Snaddon JL, Peh KSH (2020) A place-based participatory mapping approach for assessing cultural ecosystem services in urban green space. People Nature 2(1):123-137. https://doi.org/10.1002/pan3.10057

Keeler LW (2014) Quenching our thirst for future knowledge: participatory scenario construction and sustainable water governance in a desert city. Available via https://core.ac.uk/download/pdf/79572451. pdf. Accessed 20 March 2021

Kleemann J, Inkoom JN, Thiel M, ShankarS LS, Fürst C (2017) Periurban land use pattern and its relation to land use planning in Ghana, West Africa. Landsc Urban Plan 165:280-294. https://doi.org/10. 1016/j.landurbplan.2017.02.004

Koo H, Kleemann J, Fürst C (2018) Land use scenario modeling based on local knowledge for the provision of ecosystem services in Northern Ghana. Land. https://doi.org/10.3390/land7020059

Koo H, Kleemann J, Fürst C (2019) Impact assessment of land use changes using local knowledge for the provision of ecosystem services in Northern Ghana, West Africa. Ecol Indic 103(9):156-172. https://doi.org/10.1016/j.ecolind.2019.04.002

Koschke L, Fürst C, Frank S, Makeschin F (2012) A multi-criteria approach for an integrated land-cover-based assessment of ecosystem services provision to support landscape planning. Ecol Ind 21:54-66. https://doi.org/10.1016/j.ecolind.2011.12.010
Ligtenberg A, Bregt AK, Van Lammeren R (2001) Multi-actor-based land use modelling: spatial planning using agents. Landsc Urban Plan 56(12):21-33. https://doi.org/10.1016/S0169-2046(01)00162-1

Malinga R, Gordon LJ, Lindborg R, Jewitt G (2013) Using participatory scenario planning to identify ecosystem services in changing landscapes. Ecol Soc. https://doi.org/10.5751/ES-05494-180410

Martín-López B, Iniesta-Arandia I, García-Llorente M, Palomo I, CasadoArzuaga I, García DDA, Gómez-Baggethun E et al (2012) Uncovering ecosystem service bundles through social preferences. PLoS ONE. https://doi.org/10.1371/journal.pone.0038970

Ministry of Environment Science and Technology (MEST) (2011) The new spatial planning model guidelines. Available via http://www. luspa.gov.gh/files/GUIDELINES-FOR-THE-NEW-SPATIALPLANING-MODEL.pdf. Accessed 5 March 2021

Ministry of Environment Science and Technology (MEST) (2012) Western Region Spatial Development Framework. Available via http:// www.luspa.gov.gh/files/Final_WRSDF_Edition.pdf. Accessed 11 May 2021

Millennium Ecosystem Assestment (MEA) (2005) Ecosystems and human well-being. Ecosystems. https://doi.org/10.1196/annals. 1439.003

Mwangi E, Wardell A (2013) Multi-level governance of forest resources: editorial to the special feature - Part 2. Int J Commons 7(2):339-343. https://doi.org/10.18352/ijc.465

Osei D, Horwich RH, Pittman JM (2015) First sightings of the Roloway Monkey (Cercopithecus Diana Roloway) in Ghana in ten years and the status of other endangered primates in Southwestern Ghana. Afr Primates 10:25-40

Peh KSH, Balmford AP, Bradbury RB, Brown C, Butchart SHM, Hughes FMR, MacDonald MA, Stattersfield AJ, Thomas DHL, Trevelyan RJ, Walpole M, Merriman JC (2017) Toolkit for Ecosystem Service Site-based Assessment (TESSA). Version 2.0, Cambridge, UK Available via: http://tessa.tools

Plieninger T, Bieling C, Fagerholm N, Byg A, Hartel T, Hurley P, LópezSantiago TA et al (2015) The role of cultural ecosystem services in landscape management and planning. Curr Opin Environ Sustain 14:28-33. https://doi.org/10.1016/j.cosust.2015.02.006

Plieninger, T, Bieling C, Ohnesorge B, Schaich H, Schleyer C, Wolff F (2013) Exploring futures of ecosystem services in cultural landscapes through participatory scenario development in the Swabian Alb, Germany. Ecol Soc 8(3). https://doi.org/10.5751/ ES-05802-180339

Rodrigues JG, Conides A, Rodriguez SR, Raicevich S, Pita P, Kleisner K, Pita $C$ et al (2017) Marine and coastal cultural ecosystem services: knowledge gaps and research priorities. One Ecosyst 2:e12290. https://doi.org/10.3897/oneeco.2.e12290

Scholte SSK, van Teeffelen SJA, Verburg PH (2015) Integrating sociocultural perspectives into ecosystem service valuation: a review of concepts and methods. Ecol Econ 114:67-78. https://doi.org/10. 1016/j.ecolecon.2015.03.007

Xiang W-N (2019) Ecopracticology: the study of socio-ecological practice. Socio Ecol Pract Res 1(1):7-14. https://doi.org/10.1007/ s42532-019-00006-6

Xiang W-N, Clarke KC (2003) The use of scenarios in land-use planning. Environ Plann B Plann Des 30(6):885-909 

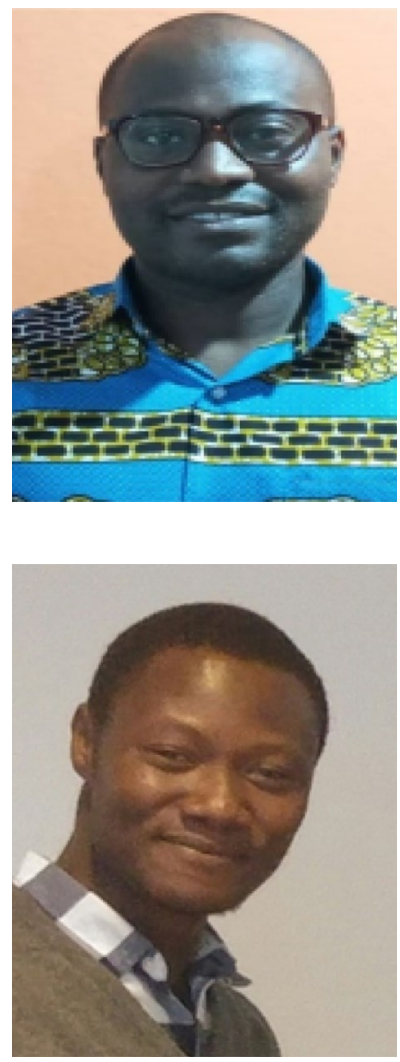

Stephen Kankam is a $\mathrm{PhD}$ candidate at the Institute for Geosciences and Geography, Martin Luther Universität, Halle-Wittenberg, Germany. He is also the Deputy Director at Hen Mpoano (Our Coast) (www.henmpoano. org), a non-governmental organization operating in Ghana, where his work involves supporting actors in government, private sector and civil society through capacity building and research in coastal and marine ecosystem governance.

Justice Nana Inkoom is a research program manager at Hen Mpoano (Our Coast), where his focus has been on the science and praxis of quantitative landscape pattern analysis, spatial planning and landscape governance. His scientific research expertise covers GIS and remote sensing applications, spatial modelling and development and applications of landscape metrics.

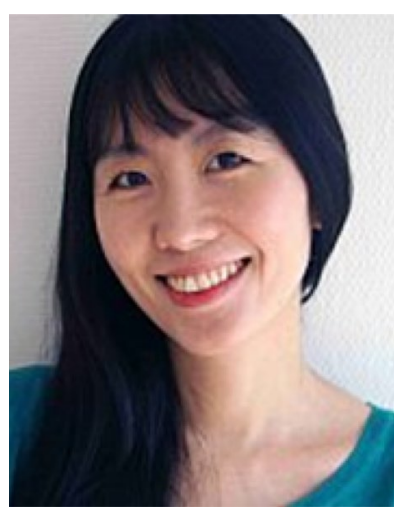

Hongmi Koo is a researcher at the Institute for Geosciences and Geography, Martin Luther Universität, Halle-Wittenberg, Germany. She is specialized in land use modeling, scenario development and ecosystem services assessments and currently working for international research consortium projects between Germany, Asia and Latin America.

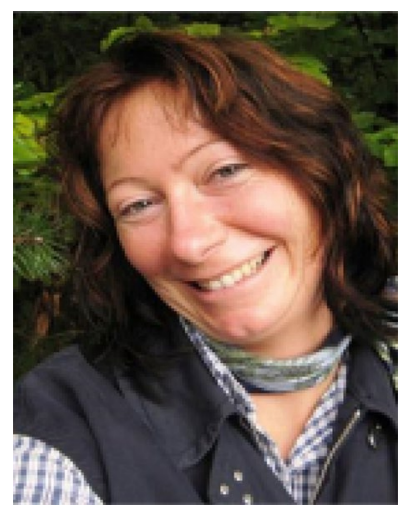

Christine Fürst is a professor of sustainable landscape development at the Martin Luther Universität, Halle-Wittenberg, Germany. Her research focuses on integrative landscape modeling, ecosystem services assessment, land-use impact assessment, and participatory urban and regional spatial planning. She has extensive research experience on projects in Europe, Africa, Asia, and Latin-America. 